\title{
Response of Cowpea to Symbiotic Microorganisms Inoculation (Arbuscular Mycorrhizal Fungi and Rhizobium) in Cultivated Soils in Senegal
}

\author{
Francis Augustin Do Rego ${ }^{1, *}$, Ibou Diop², Oumar Sadio ${ }^{3}$, Marie Claire Da Sylva ${ }^{4}$, \\ Codjo Emile Agbangba ${ }^{6}$, Omar Touré ${ }^{4}$, Aboubacry Kane ${ }^{2}$, Marc Neyra ${ }^{5}$, \\ Ibrahima Ndoye ${ }^{2}$, Tatiana Krasova Wade ${ }^{1}$ \\ ${ }^{1}$ Institut de Recherche pour le Développement (IRD), UMR040, Laboratoire Commun de Microbiologie IRD/ISRA/UCAD, Centre de \\ Recherche de Bel-Air, Sénégal \\ ${ }^{2}$ Département de Biologie Végétale, Faculté des Sciences et Techniques, Université Cheikh Anta Diop (UCAD), Laboratoire Commun de \\ Microbiologie IRD/ISRA/UCAD) Dakar-Sénégal \\ ${ }^{3}$ Institut de Recherche pour le Développement (IRD), UMR 195, LEMAR, Sénégal \\ ${ }^{4}$ Institut de Recherche Agricole (ISRA), Laboratoire Commun de Microbiologie IRD/ISRA/UCAD), Dakar-Sénégal \\ ${ }^{5}$ Institut de Recherche pour le Développement (IRD), Laboratoire des Symbioses Tropicales et Méditerranéennes, UMR113 \\ IRD-Cirad-SupAgro-UM2/USCINRA, Campus de Baillarguet, France \\ ${ }^{6}$ Université Cheikh Anta Diop, Département de Biologie végétale, Laboratoire d'Ecologie et d'Ecohydrologie, Sénégal
}

Copyright (C) 2015 Horizon Research Publishing All rights reserved.

\begin{abstract}
The response of cowpea [Vigna unguiculata (Walp. (L.)] to inoculation with symbiotic microorganisms (arbuscular mycorrhizal fungus and rhizobium) was investigated on cultivated vertisoils (known locally as Dek) and arenosoils (known locally as Dior) in three geographic sites in Senegal. On the basis of soil physico-chemical characteristics, of most probable number (MPN) of indigenous rhizobia and of yields, a hierarchical analysis showed that the sites were grouped in three clusters. Some soils initially considered as Dek were grouped with Dior, so that all of Dior soils were grouped in the same cluster. No significant increasing in shoot biomass or yield was observed when cowpea was inoculated with fungi alone, whatever soil type. However, a significant or noticeable improvement in cowpea seeds production was obtained by rhizobium inoculation. It appeared that cowpea response to inoculation depended on geographical site and were often observed in sandy arenosoils (Dior type) or in loamy sand vertisoils (Dek type) with at least $15 \mathrm{mgkg}^{-1}$ of available phosphorus level.
\end{abstract}

Keyswords Typology, Cowpea, inoculation, AM fungi, Rhizobia

\section{Introduction}

Cowpea is a grain legume that plays a very important socio-economic role especially among rural populations. Through its seeds rich in proteins $(25 \%)$, it is one of food sources available to rural population. Moreover, like other grain legumes, its cultivation also contributes to soil fertility restoration due to its high potential of biological nitrogen fixation $[1 ; 2]$.

However, despite all these interests, the average yield of cowpea is less than $300 \mathrm{~kg} / \mathrm{ha}$ but with considerable worldwide variations. For example in Africa, the average yields vary from 50 to $550 \mathrm{~kg} / \mathrm{ha}$ depending on varieties, quantity of applied fertilizers, pesticides, cropping system (intercropping versus sole cropping) and agro-climatic conditions [3].

In Senegal, the fourth producing country in West Africa, the national yield is estimated at $543 \mathrm{~kg}$ per ha in the sole cropping systems [3]. These yields are considered low compared to a potential yield that can reach up to 1000 $\mathrm{kg} / \mathrm{ha}$ and $3000 \mathrm{~kg} / \mathrm{ha}$ respectively for the Senegalese varieties Melakh and Mouride [3].These low yields are mainly related to a decrease of soil fertility namely in phosphorus $(\mathrm{P})$ and in nitrogen $(\mathrm{N})$. This is a result of an overexploitation of agricultural lands coupled with a lack of fallow. In response, the use of fertilizers and pesticides could help to raise the production of cowpea. However, the use of these inputs is limited in particular by their exorbitant cost, but also by their effects on the environment such as pollution and loss of biodiversity in the regions of intensive agriculture and the degradation of the most fragile agricultural systems [4].

Nevertheless, microbial biotechnologies could help to overcome these difficulties. Indeed, cowpea is a legume capable of forming a double symbiosis with nitrogen fixing bacteria, rhizobia, and mycorrhizal fungi to form 
symbioses.

In a mycorrhizal symbiosis, fungi ensure to their host an improvement of the hydro mineral nutrition $[5 ; 6 ; 7 ; 8]$ and a protection against soil pathogens $[9 ; 10]$. In return they receive vegetal carbon in hexose form $[11 ; 12]$ that are converted in trehalose and in glycogen [13], two forms that are unused by the plants. These microorganisms are used nowadays as bio fertilizers. However, their inoculation with plants often does not give the expected results particularly in field conditions [14]. In order to understand the causes that hinder the inoculation in the field, Verbruggen et al.[15] identified three factors: the compatibility of the species (to environment conditions), the capacity of the AM fungi to express their full potential in field and the influence of time and of the competition on the establishment of stable communities of inoculated fungi. In the same way, Johnson et al.[16] emphasized the importance of a local adaptation of the arbuscular mycorrhizal fungi and suggest identifying the soil factors that promote the symbiotic processes. One promising approach would thus be to establish a correlation between the performances of the inoculum potential and the conditions of the environment such as land use [17] and specially soil type and $\mathrm{pH}[18]$, as well as the fungus capacity to be associated with a wide range of host plants [19]. These factors deserve a special attention because it is now known that some taxa of AM fungi can be specific to a host plant or to a habitat while others can be generalists [18; 19].

The nitrogen-fixing symbiosis is an association between the soil bacteria, rhizobia (generic term), and a leguminous plant. In nitrogen-deficient conditions, the rhizobia induces the formation of nodules at the root and stem level. In the nodules, the bacteria fixes atmospheric nitrogen $\left(\mathrm{N}_{2}\right)$ and provides it to the host plant in assimilable form and in return the host plant provides to the bacteria a micro habitat exceptionally favourable and carbonaceous substances from the photosynthesis [20]. The inoculation of legume with nitrogen-fixing bacteria allows an increase of fixed nitrogen amount and of yield, an improvement of seeds' quality of $[21 ; 22]$ and a tolerance to the abiotic stresses [23]. However, the success of the nodulation of the legumes by the rhizobia in real environment is a process that depends on several soil factors such as $\mathrm{pH}$, temperature presence of aluminium, manganese, phosphorus and calcium [24]. Very diverse population of cowpea rhizobia was described in Senegal in diverse ecological zones [25].

The ethnographic investigations revealed in anterior studies in Senegal [26] the importance of soil type in perception of agricultural soil potential. Thus it was shown that conventional physicochemical parameters (texture, CEC) apprehended through observation and land use by the populations behind to pedological denominations of typological variations and agronomic potential. Indeed, two major soil types are known, vertisoils and arenosoils. They correspond to the common names of Dior and Dek, the most cultivated soils in Senegal.

The goal of this work was to study the cowpea response to inoculation with AMF fungi and rhizobia in the two soils types.

\section{Material and Methods}

\section{Sites location and soils characteristics}

Three sites of study were chosen according to the rainfall gradient, Ouarkhokh and Darou Mousty (300-500 mm of rains per year), located in the Sahelian zone, and Dya located in the Sudano-Sahelian zone $(500-700 \mathrm{~mm}$ of rains per year). On each site, four fields including two vertisoils (locally called Dek) and two arenosoils (locally called Dior) were studied in the experiment except in Dya where tree fields were studied (Table 1). These soils are the most representative in the studied zones. The Dek soil or sub-arid brown soils are loam to sandy loam soils relatively rich in organic matter and marked by a water regime of seasonal water logging. The Dek soils differ from the Dior by their richness in calcium (due to the limestone-marl sublayer) giving a better stability of the structure. The Dior is ferruginous tropical soils slightly leached. Because of their sandy texture and their low content in organic matter, they are chemically poor and acidify under the effects of a continuous cropping. They are easier to cropping than the Dek soils due to their low content in clay.

Table 1. Sampled sites and soil type of studied fields

\begin{tabular}{cccc}
\hline Sites & Field & Soil type & Soil number \\
\hline \multirow{3}{*}{ Dya } & 1 & Dek & Dek 1 \\
& 2 & Dior & Dior 2 \\
& 3 & Dek & Dek 3 \\
\hline \multirow{3}{*}{ Ouarkhokh } & 4 & Dek & Dek 4 \\
& 5 & Dior & Dior 5 \\
& 6 & Dior & Dior 6 \\
& 7 & Dek & Dek 7 \\
\hline \multirow{3}{*}{ Darou Mousty } & 8 & Dior & Dior 8 \\
& 9 & Dek & Dek 9 \\
& 10 & Dek & Dek 10 \\
& 11 & Dior & Dior 11 \\
\hline
\end{tabular}

\section{Plant material}

Cowpea Melakh variety selected by ISRA (Institut Sénégalais de Recherches Agricoles, Dakar, Senegal) for its fast growing cycle (60 days) was used in this study. It's appreciated by farmers.

\section{Fungal material}

Two AMF species, Rhizophagus irregularis (Ri) and Glomus etunicatum (Ge) were tested on cowpea under field conditions. They were provided by Laboratoire Commun de Microbiologie IRD/ISRA/UCAD (LCM, Dakar, Senegal). To prepare the inoculum, maize plants were grown for four months on sterilized soil inoculated with AMF species 
selected. The soil mixed with the mycorrhizal roots, hyphae, and spores was used as inoculum. Before inoculation, the mycorrhizal parameters and density of spores in $100 \mathrm{~g}$ of dry soil were determined for each AMF species. For Rhizophagus irregularis, the inoculum was characterized by $13.5 \%$ of mycorrhizal intensities, $95 \%$ of frequencies of mycorrhization and 86 spores / 100g of dry soil of density. Inoculum of Glomus etunicatum $(\mathrm{Ge})$ was characterized by $5.08 \%$ of mycorrhizal intensities, $76.25 \%$ of frequencies and 53 spores / 100g of dry soil density.

\section{Bacterial material}

A bradyrhizobium strain LCM Nieara was inoculated in this study. It was provided by the Laboratoire Commun de Microbiology IRD-ISRA-UCAD (LCM). It's indigenous strain isolated from nodules of cowpea plants in Senegal in previous studies. The inoculum was provided in Yeast Mannitol liquid form. The optical density measured at 600 $\mathrm{nm}$ before inoculation was at about $10^{9}$ cells per $\mathrm{ml}$ of culture.

\section{Most probable number (MPN) of native rhizobia}

Prior to inoculation, field soils was sampled to determine the most probable number (MPN) of indigenous rhizobia able to nodulate cowpea, estimated by serial dilution-plant infection count using siratro (Macroptilium atropurpureum) as trap host. Six successive ten-fold dilution series were followed with an initial dilution of 1:10[27]. Four test plants were inoculated with $1 \mathrm{ml}$ aliquots. Seedling tubes inoculated with $1 \mathrm{ml}$ of sterile distilled water served as the control. Siratro seeds were scarified and surface-sterilized with concentrated sulphuric acid for $30 \mathrm{~min}$. After treatment, the seeds were washed several times with sterile water to eliminate any trace of acid. The seeds were incubated to germinate in sterile Petri dishes containing $0.7 \%$ (w v-1) $\mathrm{YM}$ agar for $24-48 \mathrm{~h}$ in the dark and then transferred into tubes containing Jensen seedling slant agar for root nodulation trials [27]. Plants were grown under intermittent light $(16 \mathrm{~h} / 8 \mathrm{~h}$, day/night) and scored for nodulation after six weeks of incubation [28]. MPN of indigenous rhizobia was determined by statistical tables [27].

\section{Experimental design}

A randomized completely block design was used in all three studied sites. It was a square field of $24 \mathrm{~m}$ side divided in 25 randomized elementary plots with an area of $16 \mathrm{~m}^{2}$. Each elementary plot included seven rows of seven seed holes each, representing a total of 49 seed holes. The distance between the lines and between the seed holes was $60 \mathrm{~cm}$. The elementary plots were separated from each other by one meter alleys. Each treatment was repeated five times and corresponding to five elementary plots. The different treatments were Rhizophagus irregularis (Ri), Glomus etunicatum (Ge), bradyrhizobium LCM Nieara (R), Mixture of the two fungi and bradyrhizobium (MR) and Control (T).

\section{Sowing and inoculation of cowpea}

Sowings were done after a first useful rain with two seeds per pocket. The singling was performed at the stage of first leaves. The inoculation was performed at sowing with $10 \mathrm{~g}$ of AMF inoculum and $10 \mathrm{ml}$ of bacterial inoculum per pocket.

\section{Collection of plant samples}

Shoot and root biomass were sampled at the flowering stage (30 days after sowing). In each field, ten plants were randomly selected from each elementary plot, 50 plants per treatment. A total of 250 plants of the different treatments were sampled by field. Roots were then cut into small pieces placed in tubes containing $70 \% \mathrm{vv}^{-1}$ alcohol before being stored in the cold $\left(4^{\circ} \mathrm{C}\right)$. The shoot biomass of the plants from a same treatment were assembled and then dried in the oven at $80^{\circ} \mathrm{C}$ for one week. They were then weighed using an electronic balance.

\section{Collection and analysis of soils sample}

The soil was sampled before sowing. At each experimental plot, composed sample of $3 \mathrm{~kg}$ was collected in six different places from $0-40 \mathrm{~cm}$ of depth and homogenized to obtain a representative sample. The samples were analysed by the Laboratoire des Moyens Analytiques (LAMA) of Institut de Recherche pour le Développement (France). The percentages of coarse sand (CS), fine sand (FS), clay $(\mathrm{Cl})$ and silt (S) were the physical characteristics determined. Besides these, total phosphorus (TP), available phosphorus (AP), total nitrogen (TN), available nitrogen (AN) and total carbon (C) were analyzed.

\section{Determination of the mycorrhization parameters}

Roots of plants sampled were stained according to the method of Philips and Hayman [29] to assess the rates of mycorrhization. In each field, 10 slides of 10 fragments each were made, representing a total of 100 pieces of roots per treatment. The microscopic examination allowed the rating of the fragments of stained roots on a scale of 6 classes ranging from 0 to 5 [30] which allowed assessing the degree of infection of each fragment. This procedure involved scoring the proportion of cortex colonized by the endomycorhizal symbiont as follows: 0: no fungal infection, 1: trace of fungal infection, 2: less than $10 \%$ of fungal infection, 3: fungal infection ranging from 11 to $50 \%, 4$ : fungal infection ranging from 51 to $90 \%$ and 5: fungal infection over $90 \%$. These scores were used to calculate:

$$
\begin{gathered}
\mathrm{I} \%=(95 \mathrm{n} 5+70 \mathrm{n} 4+30 \mathrm{n} 3+5 \mathrm{n} 2+\mathrm{n} 1) / \text { total number of } \\
\text { observed fragments }
\end{gathered}
$$

Where $\mathrm{n}$, fragments number; $\mathrm{n} 5=$ number of fragments rated $5 ; n 4=$ number of fragments rated $4 ; n 3=$ number of fragments rated $3 ; \mathrm{n} 2=$ number of fragments rated $2 ; \mathrm{n} 1=$ number of fragments rated 1 .

$\% \mathrm{~F}=$ (number of mycorrhizal fragments / total number of observed fragments) $\mathrm{x} 100$ 


\section{Harvesting}

The harvest was performed after pod maturity. In each field, the elementary plots were harvested separately. Thus, we have five (5) repetitions per treatment. The pods were dried and peeled then the seeds were weighed.

\section{Statistical analysis of data}

The data were processed using the software $\mathrm{R}$ version 2.15.0. The data were first subjected to the test of Shapiro and homogeneity of variance. When the series respects the Normal law, the analysis of variance and the means were compared using the Newman Keuls test $(\mathrm{P}<0.05)$. Otherwise, a non-parametric test was applied. Mean values were compared with Wilcoxon test $(\mathrm{P}<0.05)$. The numerical classification using WARD algorithm was performed on individuals coordinates (soils) in the factorial plan of Principal Component of Analysis (PCA).

\section{Results}

Soil characteristics of the experimental sites

The soils of the experimental plots were characterized before the experiment (Figure 1). The results of physico-chemical parameters analysis showed that the soil typology was more marked on the site of Dya (Sudano-Sahelian zone). On this site, the percentages in fine silt (FS), coarse silt (CS), clays (C), fine sands (FS), total nitrogen (TN), total carbon (TC), total phosphorus (TP), available phosphorus (AP) and N (NH4) were higher in Dek soils than in Dior soils. The latter were opposed to Dek soils with higher percentages in coarse sands. On the sites of Ouarkhokh and Darou Mousty (Sahelian zone), the typology was less pronounced. However the Ouarkhokh soils were differentiated from those of Darou Mousty by less acidic $\mathrm{pH}$ and a higher level of $\mathrm{N}\left(\mathrm{NO}_{3}\right)$ residues.

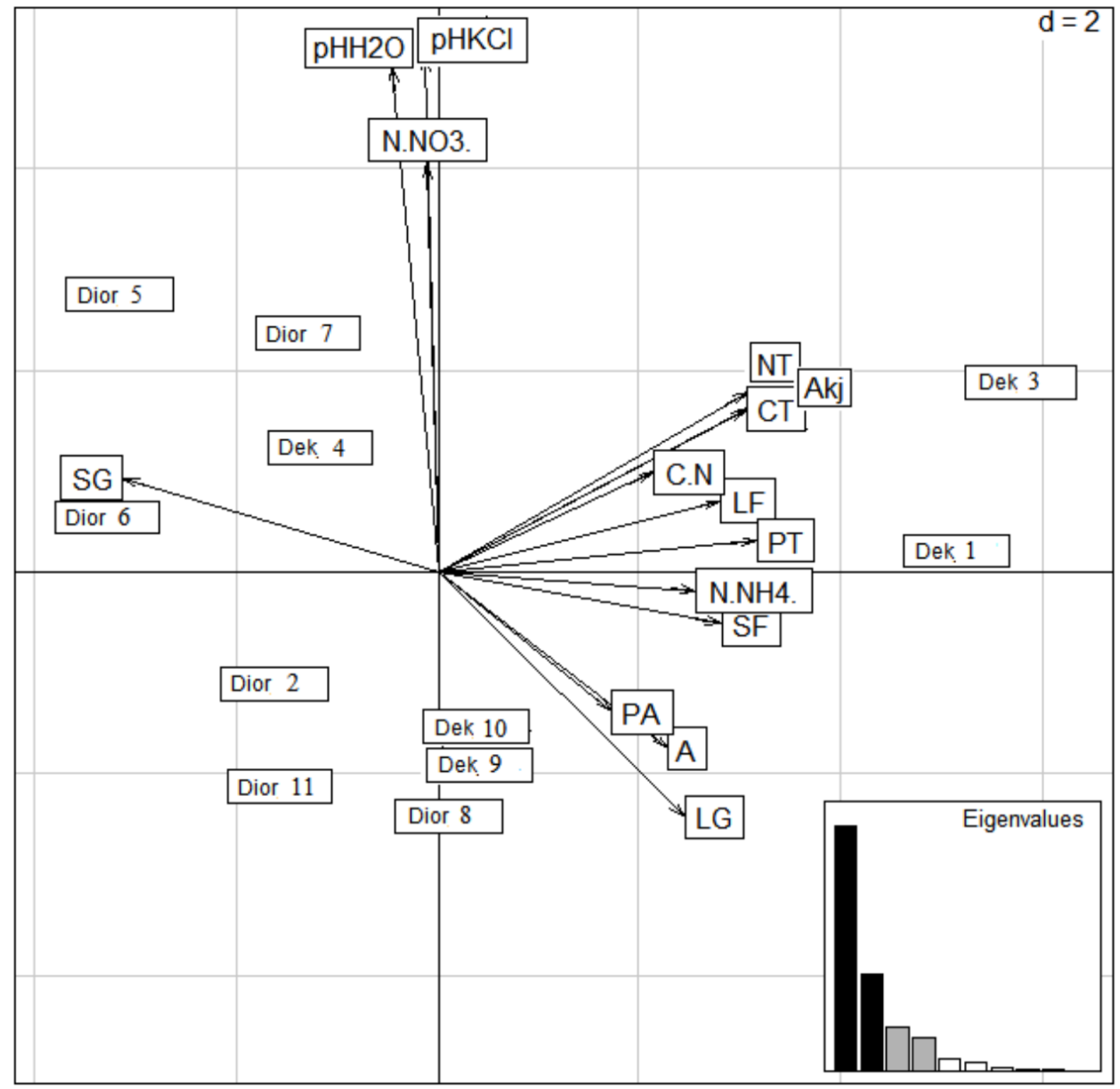

Figure 1. PCA analysis of physical and chemical characteristics of the sampled soils 
Most probable number (MPN) of native rhizobia

The estimation of rhizobia number per gram of soil showed that Dior soils were characterized by a population higher than that of the soil Dek (Figure 2). However, whatever soil type, there was variability in the same site. No rhizobia were detected in the soil Dek1.

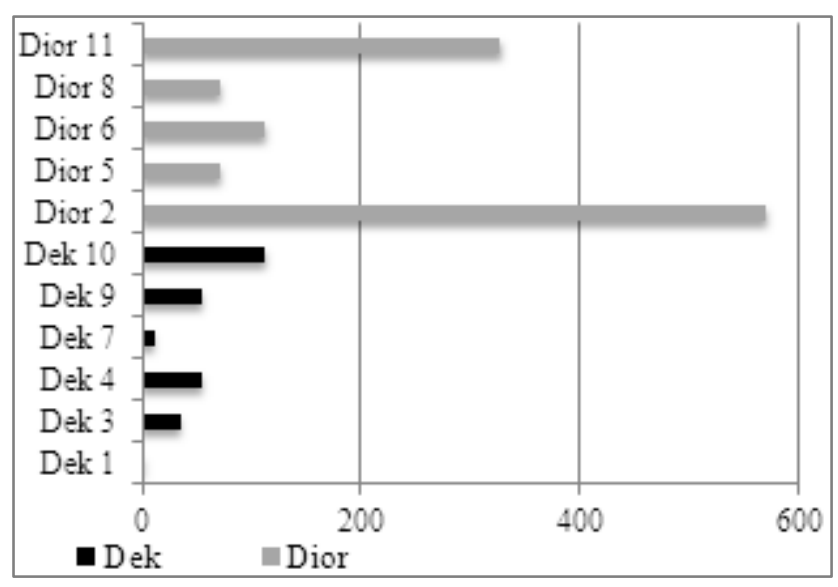

Figure 2. Estimated population of native bradyrhizobia in Dek and Dior soils by MPN (Most Probable Number). No rhizobia were detected in the soil Dek1.

\section{Effect of inoculation on cowpea mycorrhization}

After 30 days of cultivation, the effect of inoculation on cowpea mycorhization was studied (Table 2). The results indicated that in Dya, in Dior 2 soils only the treatment with Glomus etunicatum (Ge) allowed increasing significantly the intensities of mycorrhization when this treatment was compared to the control. On Dek 3 soils, only treatments Glomus etunicatum (Ge), rhizobium LCM Nieara and mixed inoculum allowed increasing the intensities of mycorrhization of cowpea. The treatment with Rhizophagus irreguralaris (Ri) had no significant effects on cowpea mycorrhization.

In Darou Mousty and Ouarkhokh, no significantly increasing of cowpea mycorrhization was found.

Effect of cowpea inoculation on shoot dry biomass

After 30 days of cowpea cultivation in Dya, no significant effect was noted on the shoot dry biomass of plants regardless of soil type (Table 3). However, a comparison between the soil types showed at least two times greater production in Dek soils than in the Dior. There was no difference when we compared the results of the two Dek fields.

Table 2. Effect of the inoculation of cowpea on the intensities of mycorrhization according to the soil type and the site

\begin{tabular}{ccccccc}
\hline \multirow{2}{*}{ Site } & Soil type & \multicolumn{5}{c}{ Intensity of mycorhization } \\
\cline { 3 - 6 } & & $\mathrm{T}$ & $\mathrm{Ri}$ & $\mathrm{Ge}$ & $\mathrm{R}$ & $\mathrm{MR}$ \\
\hline \multirow{2}{*}{ Dya } & Dek 1 & $18,37 \mathrm{a}$ & $22,33 \mathrm{a}$ & $21,97 \mathrm{a}$ & $22,74 \mathrm{a}$ & $20,33 \mathrm{a}$ \\
& Dior 2 & $29,910 \mathrm{~b}$ & $38,450 \mathrm{ab}$ & $\mathbf{3 9 , 2 5 0 a}$ & $35,510 \mathrm{ab}$ & $32,120 \mathrm{ab}$ \\
& Dek 3 & $15,48 \mathrm{C}$ & $20,840 \mathrm{bc}$ & $\mathbf{2 8 , 1 4 a b}$ & $\mathbf{2 5 , 9 8 0 a b}$ & $\mathbf{3 3 , 4 7 a}$ \\
\hline \multirow{2}{*}{ Ouarkhokh } & Dek 4 & $36,770 \mathrm{a}$ & $34,060 \mathrm{a}$ & $30,050 \mathrm{a}$ & $37,960 \mathrm{a}$ & $39,560 \mathrm{a}$ \\
& Dior 5 & $30,030 \mathrm{ab}$ & $33,090 \mathrm{ab}$ & $34,850 \mathrm{a}$ & $23,590 \mathrm{~b}$ & $33,710 \mathrm{ab}$ \\
& Dior 6 & $38,950 \mathrm{a}$ & $39,730 \mathrm{a}$ & $42,810 \mathrm{a}$ & $42,150 \mathrm{a}$ & $44,310 \mathrm{a}$ \\
& Dek 7 & $35,130 \mathrm{a}$ & $40,850 \mathrm{a}$ & $43,700 \mathrm{a}$ & $40,600 \mathrm{a}$ & $36,860 \mathrm{a}$ \\
\hline \multirow{2}{*}{ Darou Mousty } & Dior 8 & $25,300 \mathrm{a}$ & $29,000 \mathrm{a}$ & $32,770 \mathrm{a}$ & $38,670 \mathrm{a}$ & $28,570 \mathrm{a}$ \\
& Dek 9 & $25,300 \mathrm{a}$ & $29,000 \mathrm{a}$ & $32,770 \mathrm{a}$ & $38,670 \mathrm{a}$ & $28,570 \mathrm{a}$ \\
& Dek 10 & $25,300 \mathrm{a}$ & $29,000 \mathrm{a}$ & $32,770 \mathrm{a}$ & $38,670 \mathrm{a}$ & $28,570 \mathrm{a}$ \\
& Dior 11 & $36,890 \mathrm{a}$ & $37,510 \mathrm{a}$ & $42,130 \mathrm{a}$ & $37,010 \mathrm{a}$ & $39,400 \mathrm{a}$ \\
\hline
\end{tabular}

Values for each soil type followed by the same letter are not significantly different at $\mathrm{P}<0.05$ (Wilcoxon test).

Table 3. Effect of cowpea inoculation on shoot dry biomass in Dya, Darou Mousty and Ouarkhokh

\begin{tabular}{ccccccc}
\hline \multirow{2}{*}{ Site } & Soil type & \multicolumn{5}{c}{ Shoot dry biomass (g) } \\
\cline { 3 - 6 } & Dek 1 & T & Ri & Ge & R & MR \\
\hline \multirow{2}{*}{ Dya } & Dior 2 & $20,706 \mathrm{a}$ & $39,778 \mathrm{a}$ & $38,426 \mathrm{a}$ & $47,552 \mathrm{a}$ & $48,212 \mathrm{a}$ \\
& Dek 3 & $47,448 \mathrm{a}$ & $53,606 \mathrm{a}$ & $61,722 \mathrm{a}$ & $54,742 \mathrm{a}$ & $60,218 \mathrm{a}$ \\
\hline \multirow{2}{*}{ Ouarkhokh } & Dek 4 & $47,36 \mathrm{a}$ & $43,127 \mathrm{a}$ & $33,866 \mathrm{a}$ & $37,946 \mathrm{a}$ & $53,28 \mathrm{a}$ \\
& Dior 5 & $33,684 \mathrm{a}$ & $26,324 \mathrm{a}$ & $27,406 \mathrm{a}$ & $37,88 \mathrm{ab}$ & $\mathbf{5 1 , 7 3 2 b}$ \\
& Dior 6 & $16,266 \mathrm{a}$ & $14,687 \mathrm{a}$ & $12,364 \mathrm{a}$ & $14,834 \mathrm{a}$ & $10,04 \mathrm{a}$ \\
& Dek 7 & $28,582 \mathrm{a}$ & $33,894 \mathrm{a}$ & $40,914 \mathrm{a}$ & $35,262 \mathrm{a}$ & $32,24 \mathrm{a}$ \\
\hline \multirow{2}{*}{ Darou Mousty } & Dior 8 & $66,58 \mathrm{a}$ & $109,254 \mathrm{a}$ & $70,264 \mathrm{a}$ & $88,617 \mathrm{a}$ & $73,206 \mathrm{a}$ \\
& Dek 9 & $134,888 \mathrm{a}$ & $115,026 \mathrm{a}$ & $134,17 \mathrm{a}$ & $117,564 \mathrm{a}$ & $159,428 \mathrm{a}$ \\
& Dek 10 & $98,94 \mathrm{a}$ & $95,014 \mathrm{a}$ & $75,942 \mathrm{a}$ & $103,948 \mathrm{a}$ & $72,004 \mathrm{a}$ \\
& Dior 11 & $24,694 \mathrm{a}$ & $26,97 \mathrm{a}$ & $25,472 \mathrm{a}$ & $25,4 \mathrm{a}$ & $38,544 \mathrm{a}$ \\
\hline
\end{tabular}

Values for each soil followed by the same letter are not significantly different at $\mathrm{P}<0.05$ (non-parametric Wilcoxon test). 
In Darou Mousty, the same trend was observed. No significant effects were noted between the different treatments compared to the controls whatever the soil type. However, lower production in Dior 11 soils compared to the Dek 9 and Dek 10 and the Dior 8 soils was observed.

In Ouarkhokh, in Dior 5 soil the treatment mixed inoculum allowed to significantly stimulate the aerial biomass production of the cowpea.

\section{Effect of cowpea inoculation on seed yields}

In Dya, the cowpea inoculation with rhizobium LCM Nieara alone and in mixture with AM mycorrhiza improved significantly the seed production of cowpea in Dek 3 soil with an increase of $92.01 \%$ and $62.85 \%$, respectively, compared to the control (Figure 3A).
In Darou Mousty, on the Dek 9 soil, an increasing of $65.75 \%$ and $68.57 \%$ of cowpea yield was obtaining with the rhizobium LCM Nieara and the mixed treatment, respectively (Figure 3B).

On the site of Ouarkhokh, whatever the type of soil, inoculation with rhizobia alone or mixed with AMF had improved seed production (Figure 3C). Significant effects were recorded in soils Dior 6 with gains of $121.7 \%$ and $138.66 \%$, respectively, for the treatments LCM Nieara and mixed inoculum. In the Dek 4 soil, a significant increase of $84.87 \%$ was obtained with rhizobium LCM Nieara. Positive but not significant effects were obtained on the Dior 5 and Dek 7 soils with rhizobium and mixed inoculum for increasing of $53.98 \%$ and $45.16 \%$, and $98.7 \%$ and $74.02 \%$, respectively.
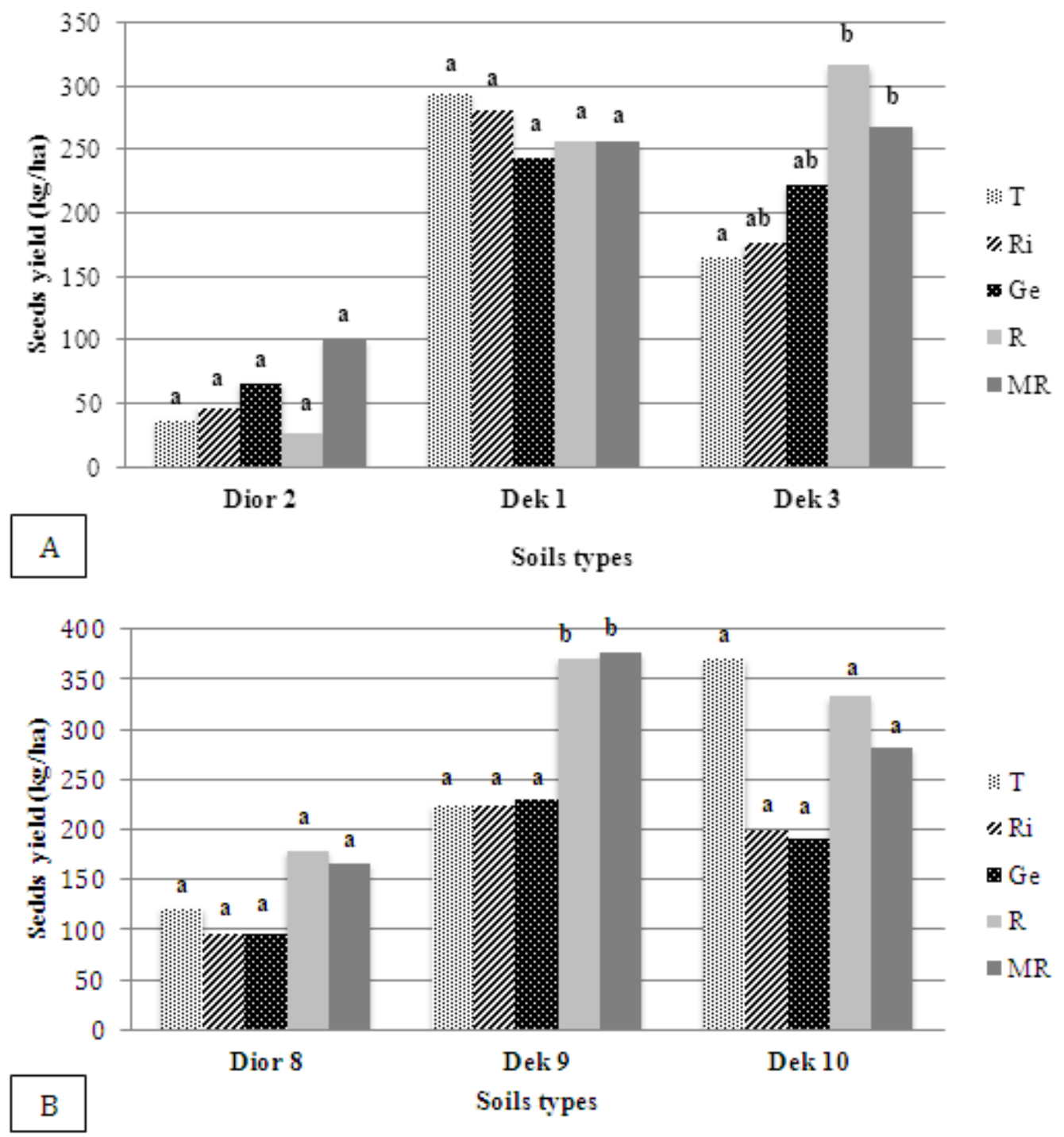


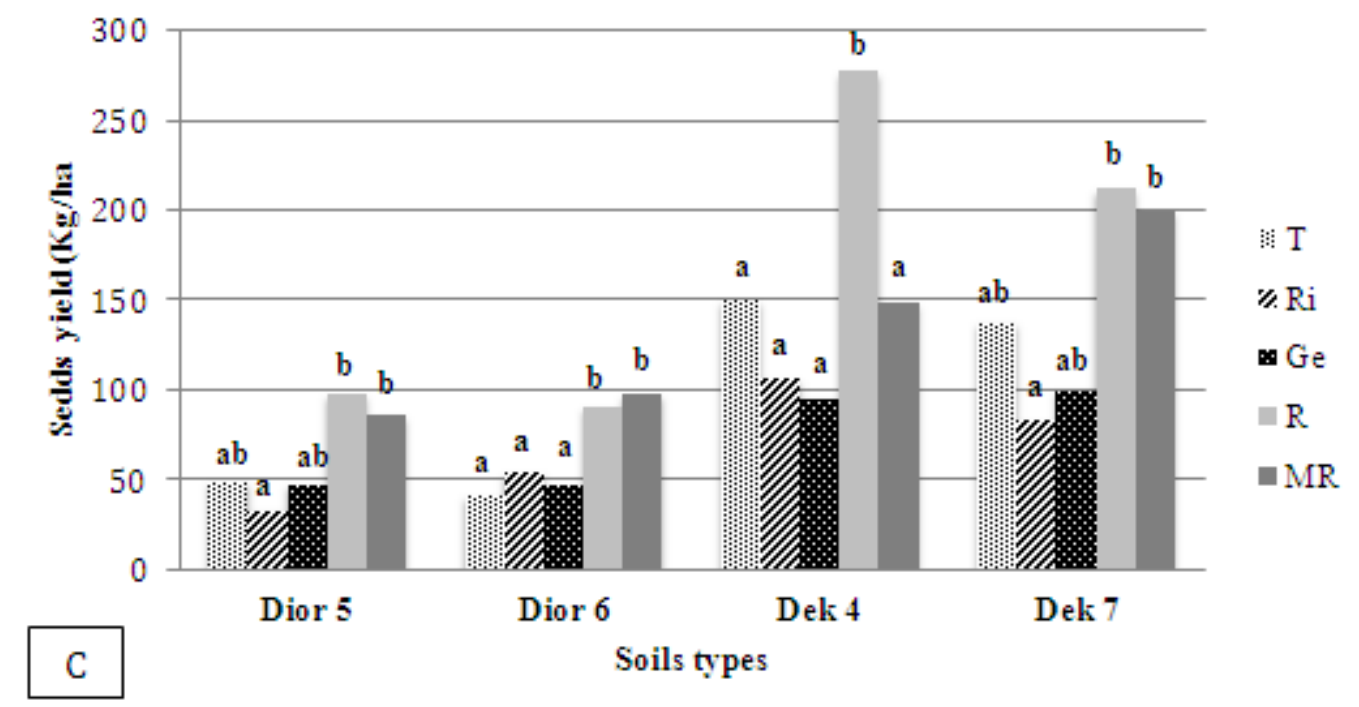

Figure 3. Effect of cowpea inoculation on seed yields. (A) in Dya, (B) in Darou Mousty, (C) in Ouarkhokh. Values for each soil followed by the same letter are not significantly different by non-parametric Wilcoxon test $(\mathrm{P}<0.05)$. Data for the Dior 2 soil is absent because of damaged production by insects. T, control; Ri, Rhizophagus irregularis; Ge, Glomus etunicatum, R, rhizobium LCM Nieara, MR, mixed inoculum of Rhizophagus irregularis and Glomus etunicatum.

Effect of cowpea inoculation aerial biomass mineral content

At the end of the cultivation (60 days after sowing) of cowpea in Dya, in the Dek 2 and Dior soils, the applied treatments did not affect mineral quality of aerial biomass, with exception to the rhizobium treatment on the Dior soil that allowed an improvement of $30.09 \%$ of phosphorus level (data not shown, supplementary table S1). On the Dek 1 , the treatments with Glomus etunicatum and rhizobium allowed a significant improvement in quantities of phosphorus also. These quantities go from $1,80 \mathrm{gkg}^{-1}$ for the control plants to $2.57 \mathrm{gkg}^{-1}$ with the Glomus etunicatum $(\mathrm{Ge})$ treatment and to $2.9 \mathrm{gkg}^{1}$ with the LCM $3682(\mathrm{R})$ treatment, to be increases of $42.77 \%$ and $62.77 \%$ respectively. Regarding the mixed inoculum treatment, it led to an increase of amounts of potassium in the aerial parts from $6.85 \mathrm{gkg}^{-1}$ to $9,25 \mathrm{gkg}^{-1}$, an increase of $35.03 \%$.

In Darou Mousty, on the soils Dek 1 and Dek 2, none of the applied treatments had positive effects on mineral quality (data not shown). Moreover, rhizobium and mixed inoculum treatments even led to a decrease of the levels of nitrogen, total carbon, phosphorus and potassium in Dek 2. We recorded a decrease of total nitrogen at $59 \%$ and $46.1 \%$ for treatments rhizobium and mixed inoculum; of phosphorus, at $35 \%$ and $33 \%$; of carbon, $54.6 \%$ and 44 , $08 \%$; of potassium, $45.98 \%$ and $18.7 \%$, respectively.

In the site of Ouarkhokh, no positive effects of the different treatments were noted in the Dior 2 soils (data not shown). The same observation was made on Dek 1. However, on this soil, the inoculation with the Rhizobium LCM Nieara strain allowed an increase in the level of total nitrogen of the leaves that go from $2.65 \%$ to $3.07 \%$, an increase of $15.8 \%$. On the other hand, the treatments did not increase the levels of total phosphorus in the aerial parts. In the Dior 1 soil, except the G. etunicatum (Ge), which allowed an increase of the phosphorus level of $21.8 \%$, the other treatments had no significant effects on the other analyzed chemical elements. On the Dek 2, there is even a decrease of the levels of total nitrogen of $23 \%, 15.75 \%$ and $28.18 \%$ for the treatments of G. etunicatum $(\mathrm{Ge})$ and the mixture fungi-rhizobium (MR), $R$. irregularis (Ri), and rhizobium (R), respectively. On the other hand, in the case of phosphorus, the treatments with Ge and MR allowed an improvement of this element with an increase of $27.2 \%$ and $218.72 \%$ respectively as compared to the control.

\section{Discussion}

Multilocational experiments conducted simultaneously in this study have allowed us to understand the effects of inoculation on the growth and yield of cowpea under various environmental conditions such as soil type, physico-chemical composition and rainfall in Senegal. The response to inoculation of cowpea in the two more cultivated soil types was studied on three sites.

Overall, regardless of inoculation data, the results indicate a low aerial biomass and yields in Dior soils compared to Dek soils. This could be explained by the fact that the Dior soils are poorer than Dek soils in mineral elements. Indeed Dior soils are in high topographical position while Dek soils are in a closed depression zone forming a receptacle of runoff. Also Dior soils are characterized by a mineralogical cortege dominated by kaolinite, a mineral characterized by a low cation exchange capacity. This low cation exchange capacity and weak organic matter content combined with leaching caused by runoff could explain the low fertility in Dior soils. In contrast, the cation exchange complex (CEC) and the sum of exchangeable bases are higher in Dek soils due to their clay content and organic matter compared to Dior soils. This therefore results in a higher fertility in soils 
Dek.

Improving of seed production was obtained by inoculation, significantly when the rhizobium strain was inoculated in mixed inoculum with arbuscular mycorrhizal fungi in Dek 3, Dek 9, Dior 6 or in the Dek 4 soil where positive results were obtained with rhizobium alone. ANOVA analysis failed to diagnosis any interactions between soil type and the positive effect of inoculation in some soils (Table 4). Interestingly, the soils with positives inoculation effects were clustered into three distinguished groups on the basis of their physico-chemical, biological (MPN) characteristics and yields (Figure 4). One group was mixed by Dior 2, Dior 5, Dior 6, Dek 4 and Dek 7 soils (all showing significant or apparent inoculation positive effects), a second one, by the Dek1 and Dek 3, or a third, by Dior 8, Dek 9 and Dek10. Referring to the texture triangle (Jamagne, 1967 cited by Tournebize[51]) revealed in fact that the soils Dek4 and Dek 7 fell into sandy soils(Dior) rather that into sandy loam (Dek). Inversely, the Dior 8 soil was grouped with loamy sand soils (Dek). Thus we can say that unlike previous work of Jankowski and Le Marec[26], local name does not always correspond to the conventional soil definition. The Dek 3 and Dek 9 soils have been distinguished.

Table 4. ANOVA analysis of factors effects

\begin{tabular}{cccccc}
\hline Factor & DDL & Sum of squares & Mean squares & F & $\operatorname{Pr}>\mathrm{F}$ \\
\hline Site & 2 & 430882,017 & 215441,009 & 30,839 & $<0,0001$ \\
Type de sol & 1 & 1059400,642 & 1059400,642 & 151,648 & $<0,0001$ \\
Traitements & 4 & 296235,705 & 74058,926 & 10,601 & $<0,0001$ \\
Site*Type de sol & 2 & 116386,078 & 58193,039 & 8,330 & 0,000 \\
Site*Traitements & 8 & 72849,797 & 9106,225 & 1,304 & 0,243 \\
Type de sol*Traitements & 4 & 57120,145 & 14280,036 & 2,044 & 0,089
\end{tabular}

\section{Hierarchical Clustering}
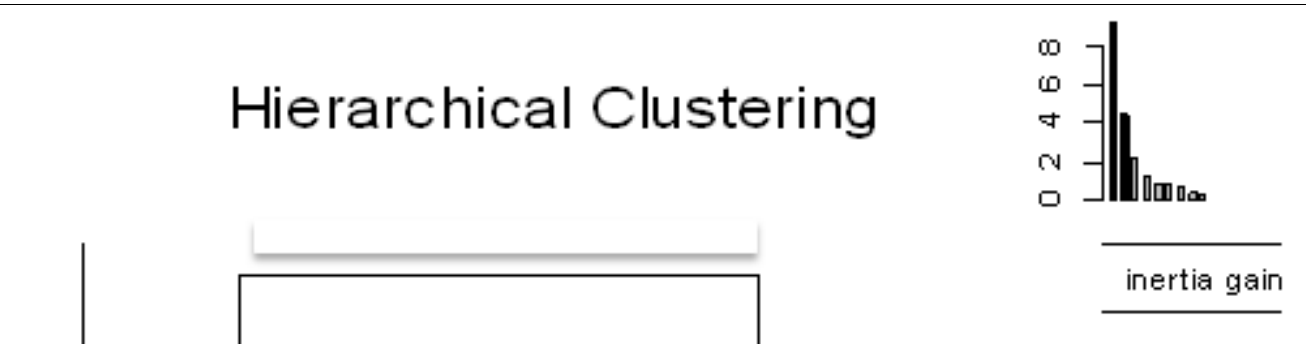

Figure 4. Dendogram relating the sampled soils on the basis of physico-chemical, biological (MPN) characteristics and yield. Asterisks design soils with positive (Dek3, Dek 4, Dior 6, Dek 9) or apparent (Dior 2, Dior 5, Dek 7) effects of inoculation. 
In contrast, the results showed that the inoculation has no effect on the dry shoot biomass of cowpea regardless of the soil type and site, except in Dior 5. As observed in Dek 3, Dek 4 and Dior 6, Li et al.[31] showed also that fungi could repress a vegetative growth of plants and increase yield and level of phosphorus of wheat seeds. These authors explain such results by functional strategies of symbiotic fungi that depend on the growth stage of the host plants. Similar results were also noted by Lekberg and Koide [32]. According to these authors, these results could be explained by a limited plant growth, phosphorus level in soil, stresses such as drought, pest infestation, predation or competition or deficiency in other elements. Diem and Gauthier [33] noticed an increase in the amount of leaf phosphorus of inoculated Casuarina equisetifolia with Glomus mosseae, without an increase of the biomass and concluded that the soil nitrogen would be a limiting factor in the conditions of their experimentation.

Many parameters such as genotypes and development stages of vegetal partners, environmental conditions (nutrient availability, light intensity) and the interaction between communities could affect response to inoculation $[34 ; 35 ; 36 ; 37]$. In this study in Senegal, soil conditions, in particular the nutrient availability, appear to be the main factor limiting the mycorrhization. Indeed, the results of the physicochemical analysis of the different types of soil revealed that Dek3 in Dya and the Dek9 in Darou Mousty exhibit higher phosphorus levels than the other fields and that they are noted the improvements of the yield. These results are consistent with earlier research which showed that the mycorrhization is depending on available phosphorus level in the soil and that a low content inhibits the mycorrhization $[38 ; 39 ; 40]$ and increases the carbon cost of the symbiosis $[41 ; 42]$. This could lead to a neutral or negative response of the plants. Similar works revealed a decrease of the fungal mycelium growth when the availability of nitrogen and phosphorus falls below a certain threshold [43]. A decrease of fungi mycelium growth may result in decreasing of amount of absorbed phosphorus by the fungal way especially since it is correlated to the amount of extra radical hyphae produced by the fungus [6; 44].

The lack of positive response could also result from poorly adaptation of the fungal inoculum to the experiment conditions. Indeed, the inoculum strains used in this study are exotic and spores densities brought were low (86 and 53 spores per 100 grams of soil, for R.irregularis and $G$. etunicatum respectively) compared to those of some local morphotypes like Gigaspora ssp(over 300 spores per 100 grams of soil especially in Dek soils [45]). Recently research showed that when introduced arbuscular mycorrhizal fungi are poorly represented, they can easily be dominated by the soil indigenous fungi [15]. For that reason, Pellegrino et al.[46] suggest that the density of the applied inoculum should be strictly equivalent to that of the indigenous populations for successful inoculations in the field, hence the need to determine the densities of the populations of indigenous fungi in each soil type. Furthermore, small root fragments can be heavily colonized by several AM fungi belonging to several species [45]. Species belonging to the family of Gigasporaceae are largely dominant in the roots of cowpea (I. Diop, non-published data). They are deemed to be very efficient in the absorption of phosphorus through an extensive network of extra radical hyphae developed to explore a large soil volume than other species $[47 ; 48 ; 49 ; 50]$. These characteristics make them better competitors compared to the inoculated strains that would explain no positive response to inoculation.

It appears from these studies that the positive results of cowpea inoculation could be explained by performances of inoculated rhizobium and positive interactions with native endomycorhizal fungus. These results were found in the Dek 3 and Dek 9 soils where phosphorus level was superior or equal to $15 \mathrm{mgkg}^{-1}$ before cowpea plantation (Supplementary table S2) or in the Dior soils, except the Dior 2 soil, characterized by a high native rhizobial population.

In conclusion, the results of cowpea inoculation in a real environment in Senegal showed that the tested rhizobium alone allowed improving seed production. Nevertheless, the improvement is depending on geographical site and it is generally observed in sandy arenosoils (Dior type) and in loamy sand vertisoils (Dek type) with available phosphorus level of $15 \mathrm{mgkg}^{-1}$ at least.

\section{Acknowledgments}

This work was supported by Agence Nationale Française de la Recherche (SolAO-ANR-08-VULN-011) and by Agence Universitaire de la Francophonie (Project BAO-2011-06-U-52210FT109). The authors are grateful for farmers and their agricultural advisors of the Communes of Dya, Darou Mousty and Ourakhokh for their contribution and partnership in this work.

\section{REFERENCES}

[1] Bado BV. Rôle des légumineuses sur la fertilité des sols ferrugineux tropicaux des zones guinéenne et soudanienne du Burkina Faso. [Thèse de doctorat]. Québec: Université Laval 2002.

[2] Graham PH, Vance CP. Legumes: importance and constraints to greater use. Plant Physiology. 2003;131(3):872-7.

[3] Cissé N, Hall AE. Traditional Cowpea in Senegal, cas study. 2003.

www.fao.org/ag/AGP/AGPC/doc/Publicat/cowpea_cisse/cow pea_cisse_e.htm

[4] Plenchette C, Clermont-Dauphin C, Meynard JM, Fortin JA. Managing arbuscular mycorrhizal fungi in cropping systems. Canadian Journal Plant Science. 2005;85:31-40.

[5] Augé RM. Arbuscular mycorrhizae and soil/plant water relations. Canadian Journal of Soil Science. 
2004;84:373-81.

[6] Drew EA, Murray RS, Smith SE, Jakobsen I. Beyond the rhizosphere: growth and function of arbuscular mycorrhizal external hyphae in sands of varying pore sizes. Plant and Soil. 2003;251:105-14.

[7] Smith SE, Smith FA, Jakobsen I. Mycorrhizal fungi can dominate phosphate supply to plants irrespective of growth responses. Plant Physiology. 2003;133:16-20.

[8] Avio L, Pellegrino E, Bonari E, Giovannetti M. Functional diversity of arbuscular mycorrhizal fungal isolates in relation to extraradical mycelial networks. New Phytologist. 2006;172:347-57.

[9] Wehner J, Antunes PM, Powell JR, Mazukatow J, Rillig MC. Plant pathogen protection by arbuscular mycorrhizas:A role for fungal diversity? Pedobiologia. 2009.

[10] Khan MH, Meghvansi MK, Panwar V, Gogoi HK, Singh L. Arbuscular mycorrhizal fungi- induced signalling in plant defence against phytopathogens. Journal of Phytology. 2010;2(7):53-69.

[11] Shachar-Hill Y, Pfeffer PE, Douds D, Stanley F.Osman, Doner LW, Ratcliffe RG. Partitioning of intermediary carbon metabolism in vesicular-arbuscular mycorrhizal leek. Plant Physiology. 1995;108:7-15.

[12] Solaiman MDZ, Saito M. Use of sugars by intraradical hyphae of arbuscular mycorrhizal fungi revealed by radiorespiroraetry. New Phytologist. 1997;136:533-8.

[13] Bago B, Pfeffer PE, Shachar-Hill Y. Carbon metabolism and transport in arbuscular mycorrhizas. Plant Physiology. 2000;124:949-57.

[14] Callaway RM, Walker LR. Competition and facilitation: a synthetic approach to interactions in plant communities. Ecology. 1997;78:1958-65.

[15] Verbruggen E, van der Heijden MGA, Rillig M, C., Kiers ET. Mycorrhizal fungal establishment in agricultural soils: factors determining inoculation success. New Phytologist. 2013;197:1104-9.

[16] Johnson NC, Wilson GWT, Bowkera MA, Wilson JA, Miller RM. Resource limitation is a driver of local adaptation in mycorrhizal symbioses. PNAS. 2010;107(5):2093-8.

[17] Schnoor TK, Lekberg Y, Rosendahl S, Olsson PA. Mechanical soil disturbance as a determinant of arbuscular mycorrhizal fungal communities in semi-natural grassland. Mycorrhiza. 2010.

[18] Oehl F, Laczko E, Bogenrieder A, Stahr K, Bösch R, van der Heijden M, Sieverding E. Soil type and land use intensity determine the composition of arbuscular mycorrhizal fungal communities. Soil Biology \& Biochemistry. 2010;42:724e38.

[19] Öpik M, Moora M. Missing nodes and links in mycorrhizal networks. New Phytologist. 2012;194:304-6.

[20] Dommergues Y, Duhoux E, Diem HG. Les arbres fixateurs d'azote : Caractéristiques fondamentales et rôle dans l'aménagement des écosystèmes méditerranéens et tropicaux avec références particulières aux zones subhumides et arides. ed. CIRAD, FAO, IRD. Paris, France.1999.

[21] Khan MS, Zaidi A, Amil M. Associative effect of Bradyrhizobium sp. (Vigna) and phosphate solubilizing bacteria on mungbean [Vigna radiata (L.) Wilczek]. Biojournal. 1997;9:101-6.

[22] Saini VK, Bhandari SC, Tarafdar JC. Comparison of crop yield, soil microbial $\mathrm{C}, \mathrm{N}$ and $\mathrm{P}, \mathrm{N}$-fixation, nodulation and mycorrhizal infection in inoculated and non-inoculated sorghum and chickpea crops. Fied Crop Research. 2004;89:39-47.

[23] Diouf D, Duponnois R, Ba AT, Neyra M, Lesueur D. Symbiosis of Acacia auriculiformis and Acacia mangium with mycorrhizal fungi and Bradirhizobium spp. improves salt tolerance in greehouse conditions. Functional Plant Biology. 2005;32:1143-52.

[24] Toro N. Nodulation competitiveness in the Rhizobium-legume symbiosis. Word Journal of Microbiology \& Biotechnology. 1996;12:157-62.

[25] Krasova-Wade T, Le Quéré A, Laguerre G, N'Zoué A, Ndione J-A, doRego F, Sadio, O, Ndoye I, Neyra M. Eco-geographical diversity of cowpea bradyrhizobia in Senegal ismarked by dominance of two genetic types. 2014. Syst Appl Microbiology.

[26] Jankowski F, Le Marec J. Légitimation des savoirs environnementaux dans un programme de recherche participative au Sénégal. Revue Nature Sciences Sociétés.2014;22:15-22.

[27] Vincent JM. A manual for the practical study of root nodule bacteria. International Biological programme handbook no 15 Blackwell Scientific Publ Ltd, Oxford, United Kingdom. 1970.

[28] Menyah MK, Sato K. Survival of inoculant Bradyrhizobium japonicum in an Andosol. Biology and Fertily of Soils. 1996;23:105-9.

[29] Philips J M, Hayman D S. Improved procedures for cleaning roots and staining parasitic and vesicular arbuscular mycorrhizal fungi for rapid assessment of infection. Transactions of the British Mycological Society. 1970;55:158 -161 .

[30] Trouvelot A, Kough JL, Gianinazzi-Pearson V. Mesure du taux de mycorhization VA d'un système radiculaire. Recherche de méthodes d'estimation ayant une signification fonctionnelle: In Physiological and genetical Aspect of Mycorrhizae. Proceeding of the 1st European Symposium on mycorrhizae (Ed.V. Gianinazzi-Pearson \& S. Gianinazzi), pp.217-221. Institut National de la Recherche Agronomique, Paris.

[31] Li H, Smith FA, Dickson S, Holloway RE, Smith SE. Plant growth depressions in arbuscular mycorrhizal symbioses: not just caused by carbon drain? New Phytologist. 2008;178:852-62.

[32] Lekberg Y, Koide RT. Is plant performance limited by abundance of arbuscular mycorrhizal fungi? A meta-analysis of studies published between 1988 and 2003. New Phytologist. 2005;168:189-204.

[33] Diem HG, Gauthier D. Effet de l'infection endomycorhizienne (Glomus mosseae) sur la nodulation et la croissance de Casuarina equisetifolia. Comptes Rendus de l'Académie des Sciences, Paris. 1982;294 (3):215-8.

[34] Cavagnaro TR, Smith FA, Hay G, Carne-Cavagnaro VL, Smith SE. Inoculum type does not affect overall resistance of 
an arbuscular mycorrhiza-defective tomato mutant to colonisation but inoculation does change competitive interactions with wild-type tomato. New Phytologist. 2004;161:485-94.

[35] Facelli E, Smith SE, Facelli JM, Christophersen HM, Andrew Smith FA. Underground friends or enemies: model plants help to unravel direct and indirect effects of arbuscular mycorrhizal fungi on plant competition. New Phytologist. 2010;185:1050-61.

[36] Johnson NC, Graham JH, Smith FA. Functioning of mycorrhizal associations along the mutualism-parasitism continuum. New Phytologist. 1997;135:575-85.

[37] Jones MD, Smith SE. Exploring functional definitions of mycorrhizas: Are mycorrhizas always mutualisms? Canadian Journal of Botany. 2004;82:1089-109.

[38] Amijee F, Tinker PB, Stribley DP. The development of endomycorrhizal root systems. New Phytologist. $1989 ; 111: 435-46$

[39] Pierart A. Interactions entre mycorhization, nutrition en phosphore et adaptation de la plante à la toxicité du nickel sur substrat ultramafique:Vers une optimisation de la Mycorhization d"Alphitonia neocaledonica.Mémoire de fin d'études.Université de la Nouvelle-Calédonie 2012. p. 42.

[40] Lagrange A. Études écologique et microbiologique des espèces du genre Costularia (Cyperaceae), pionnières des sols ultramafiques en Nouvelle- Calédonie : perspectives d"application à la restauration écologique.Thèse de Doctorat,Université de la Nouvelle Calédonie. 2009.

[41] Schroeder MS, Janos DP. Phosphorus and intraspecific density alter plant responses to arbuscular mycorrhizas. Plant and Soil. 2004;264:335-48.

[42] Schroeder MS, Janos DP. Plant growth, phosphorus nutrition, and root morphological responses to arbuscular mycorrhizas, phosphorus fertilization, and intraspecific density. Mycorrhiza. 2005;15:203-16.
[43] Treseder KK, Allen MF. Direct nitrogen and phosphorus limitation of arbuscular mycorrhizal fungi: a model and field test. New Phytologist. 2002;155:507-15.

[44] Smith SE, Smith FA, Jakobsen AI. Functional diversity in arbuscular mycorrhizal (AM) symbioses: the contribution of the mycorrhizal $\mathrm{P}$ uptake pathway is not correlated with mycorrhizal responses in growth or total $\mathrm{P}$ uptake. New Phytologist. 2004;162:511-24.

[45] Diop I. Les champignons mycorhiziens arbusculairesindigènes associés au niébé (Vigna unguiculata (L.)Walp.sur trois types de sols:Diversité et impact de l'inoculation sur la culture (Thèse Unique]. Université Cheikh Anta Diop (Dakar-Sénégal). 2014.

[46] Pellegrino E, Turrini A, Gamper HA, Cafa G, Bonari E, Young JPW, Giovannetti, M. Establishment, persistence and effectiveness of arbuscular mycorrhizal fungal inoculants in the field revealed using molecular genetic tracing and measurement of yield components. New Phytologist. 2012;194:810-22.

[47] Smith FA, Jacobsen I, Smith SE. Spatial differences in acquisition of soil phosphate between two arbuscular mycorrhizal fungi in symbiosis with Medicago truncatula. New Phytologist. 2000;147:357-66.

[48] Klironomos J. Host-specificity and functional diversity among arbuscular mycorrhizal fungi. Plant-Microbe Interactions. 2000.

[49] Hart MM, Reader RJ. Host plant benefit from association with arbuscular mycorrhizal fungi: variation due to differences in size of mycelium. Biology and Fertility of Soils. 2002;36:357-66.

[50] Maherali $\mathrm{H}$, Klironomos JN. Influence of phylogeny on fungal community assembly and ecosystem functioning. Science. 2007;316.

[51] Tournebize J. Impacts de l'enherbement du Vignoble alsacien sur le transfert des nitrates. Strasbourg: Louis Pasteur; 2001. 